\title{
Büyük Patlama ve Ötesi *
}

\author{
WILLIAM LANE CRAIG \\ Tercüme: FEHRULLAH TERKAN \\ fterkan@gmail.com
}

\section{TEMEL MESELE}

Çok eski zamanlardan beri insanlar bakışlarını semaya döndürmüş ve hayret/merak etmislerdir. Hem kozmoloji ve hem de felsefe, kendi köklerini kadim Yunanlıların kozmosu tefekkür ederken hissettikleri bu meraka irca ederler. Aristo'ya göre,

İşte onların merakları sayesindedir ki insanlar hem şimdi felsefe yapmaya başlıyorlar hem de başlangıçta felsefe yapmaya başladılar. Onlar ilk başta bariz zorluklarla hayrete düştüler, daha sonra yavaş yavaş ilerlediler ve daha büyük meseleler hakkındaki zorlukları ifadeye döktüler; mesela, Ay, Güneş ve yıldız olguları ve evrenin başlangıcıyla alakalı [olan zorluklar]. ${ }^{1}$

Bizzat Aristo kabul etmiştir ki evren, ezelidir, fakat kozmos içerisindeki hareket ve değişimin kaynağı olarak, kendisinin Tanrı ile özdeşleştirdiği bir "Hareket-etmeyen Muharrik" var olmalıdır.

Milattan sonraki dönemde Kilise Babaları, Hıristiyan öğretisinin izahı için Yunan felsefi düşüncesine dayanmalarına rağmen, [sırf] Aristocu mad-

W. L. Craig tarafindan 17 Nisan 2009 tarihinde Ankara Üniversitesi İlahiyat Fakültesi’nde Beşinci Kat Seminerleri çerçevesinde sunulan "Beyond the Big Bang" başlıklı konferansın Türkçe metnidir. Metaphysics A. 2. $982^{\mathrm{b}} 10-15$. 
denin ezeliliği öğretisinin ${ }^{2}$ hatırına Kutsal Kitab'ın yoktan yaratma öğretisinden ödün vermeyi reddettiler. Aristo alemin ezeliliğini sadece iddia etmekle kalmamış fakat aynı zamanda deliller getirmiş olduğu için, Hıristiyan teologlar Kutsal Kitab'ın metin-kanıtlarını zikretmekle yetinmediler ve fakat Yunan düşünürlerini kendilerinin rakip paradigmalarının felsefi tartışmaları içine çektiler; bu şekilde dünyanın geçmiş sonluluğu ve dolayısıyla da yarat1lış öğretisi lehine argümanlar temin etmeyi amaçladılar. İslam'ın gelişinden önce yoktan yaratmanın son büyük savunucusu, İskenderiyeli Aristo şarihi John Philoponus'dur (ö.580?), ki [bu şarih] Against Aristotle (Aristo'ya Karş1) ve On the Eternity of the World against Proclus (Dünya'nın Ezeliliği Hakkında Proclus'a Karşı) adlı eserlerinde, olayların sonsuz zamansal [geriye doğru] teselsülünün imkansızlığını temel alarak yoktan yaratma öğretisi için deliller ortaya koymuştur. Müslümanların Kuzey Afrika'yı fetihlerini müteakiben, Philoponus'un aracılık ettiği gelenek, tekrar Hıristiyan skolastik teolojiye geri aktarılmasından önce, orta çağdaki Müslüman ve Yahudi teologlar tarafından ele alındı ve akabinde zenginleștirildi. Dünyanın ezeliliği üzerine yapılan tartışmalar, nihayetinde, modern çağda Immanuel Kant'ın zamanla alakalı ilk antinomisinin tezi ve anti-tezinde takdis edildi.

Gelişimine Müslümanların yaptıkları katkıları takdir etme adına "Kelam kozmolojik argümanı" diye tesmiye etmiş olduğum argümanın temel formu basittir:

1. Varlığının başlangıcı olan her şeyin bir nedeni vardır.

2. Alemin varlığının bir başlangıcı vardır.

3. Dolayısıyla, alemin bir nedeni vardır.

Evrenin bir sebebinin olmasının ne demek olduğunun kavramsal bir analizi, şu halde, bu varlığın teolojik açıdan önemli özelliklerinin bazılarını tesbit etmeyi amaçlamaktadır.

Birkaç yüzyıl boyunca gözden düştükten sonra, bu argüman son y1llarda zaman ve mekanın bir başlangıcı olduğu düşüncesi lehine çağdaş astrofiziksel kozmolojinin şaşırtıcı empirik kanıtının kuşkusuz tahrik ettiği bir ilgi patlaması yaşamaktadır. Bu argüman dikkatli bir incelemeyi hak ediyor. 


\section{BAŞLANGICI OLAN HER ŞEYİN BİR NEDENİ VARDIR}

Öncül 1, açıkça doğru gözüküyor - en azından, onun olumsuzlanmasından daha doğru. Her şeyden önce, onun [öncül 1] temeli, bir şey yokluktan varlığa çıkmaz şeklindeki metafiziksel sezgiye dayalıdır. Şeylerin, nedensiz bir şekilde yokluktan varlığa çıkabileceğini ileri sürmek, ciddi metafizik yapmayı bırakmak ve sihre başvurmak demektir. İkinci olarak, eğer gerçekten eşya nedensiz bir şekilde varlığa çıkabilirse, o zaman neden her hangi bir şeyin veya her şeyin nedensiz olarak yokluktan varlığa çıkmadığı açıklanamaz hale gelir. Son olarak, ilk öncül, bizim tecrübemizle sürekli olarak teyid edilmektedir. Dolayısıyla, teist olmayan bilimsel tabiatçılar, onu kabul etmek için en güçlü motivasyona sahiptirler.

\section{ALEMIN BAŞLANGICI VARDIR}

Eğer başlangıcı olan her şeyin bir nedeninin var olduğunu kabul edersek, argümandaki önemli ikinci adımı, yani "alemin bir başlangıcı vardır" [öncülünü] desteklemek için ne gibi bir kanıt bulunmaktadır? İkinci öncülü destekleyen hem dedüktif, felsefi argümanları hem de indüktif, bilimsel kanitı inceleyeceğiz.

\section{Felsefi Argüman:}

\section{Bilfiil Sonsuzluğun İmkansızlı̆̆ı}

$\mathrm{Bu}$ argüman üç adımda formüle edilebilir:

4. Bilfiil sonsuz sayıda şeyler var olamaz.

5. Zaman içerisinde bir başlangıçsız olaylar dizisi, bilfiil sonsuz say1daki şeyleri gerektirmektedir.

6. Şu halde, zaman içerisinde bir başlangıçsız olaylar dizisi var olamaz.

Her bir öncülü sırasıyla inceleyelim.

Bilfiil sonsuz sayıda şeyler var olamaz. İlk önermenin anlaşılmasında hayati olan şey, bilkuvve sonsuz ve bilfiil sonsuz arasındaki ayrımdır. Bilfiil sonsuz, sayısı herhangi bir doğal sayıdan $(0,1,2,3 \ldots)$ daha büyük olan bir belirli ve ayrık (süreksiz) üyeler koleksiyonudur. Bu tür sonsuzluk, küme teorisinde, $\{0,1,2,3, \ldots\}$ gibi sonsuz sayıda üyeye sahip olan kümeleri be- 
lirtmek için kullanılmaktadır. Bunun aksine, bir bilkuvve sonsuz, bir sınır olarak sonsuzluğa doğru artarak giden, fakat hiç bir zaman oraya varamayan bir koleksiyondur. Böyle bir koleksiyon, gerçekte belirsizdir, sonsuz değil. Örneğin, her hangi bir sonlu mesafe, bilkuvve olarak sonsuz sayıda çok cüzlere bölünebilir. İnsan sadece cüzleri ikiye böler durur, fakat hiçbir zaman gerçek bir "sonsuzuncu" bölmeye ulaşamaz veya cüzlerin bilfiil sonsuz say1sını ortaya çıkaramaz. Şimdi 4. Öncülün iddia ettiği şey, bilkuvve [potansiyel] sonsuz sayıda eşyanın var olamayacağı değil, fakat bilfiil sonsuz sayıda eşyanın var olamayacağıdır.

$\mathrm{Bu}$ argüman türünün, 19 yy. matematikçisi Georg Cantor'un bilfiil sonsuz üzerine yazdığı eseri tarafından ve set teorisindeki bilfiil sonsuz anlay1şını meşrulaştırmış olan müteakip gelişmeler tarafından etkisiz hale getirildiği sıklıkla iddia edilmektedir. Fakat bu, çok fazla aceleyle yapılmış bir iddiadır. Bu [iddia], sadece, belli matematikçilerin [Sezgiciler] bilfiil sonsuzun matematiksel meşruiyetini inkar etmeleri aleyhine değil, fakat aynı zamanda daha ciddi bir şekilde, matematiksel nesnelere dair anti-realist görüşler aleyhine de olabilecek şekilde, kanıtlanması gereken şeyi varsaymaktadır. ${ }^{3}$ Çoğu anti-realistler, bilfiil sonsuza matematiksel meşruiyet atfetmekten kaçınan sezgici ifrata düşmezler. Onlar sadece, bazı nosyonların matematiksel meşruiyetinin kabul edilmesinin, çeşitli nesnelerin metafiziksel gerçekliğine bağlanmayı gerektirmediğinde 1srar ederler. Cantor'un sistemi ve küme teorisi, basitçe bir söylem evrenidir, benimsenen bazı aksiyomlara ve uylaşımlara dayalı matematiksel bir sistemdir. Matematiksel nesnelere dair Fictionalism, Figuralism, veya Constructibilism gibi anti-realist görüşlere göre, matematiksel söylem hiçbir şekilde kısaltılmamıştır, fakat buna rağmen, bırakınız sonsuz sayıda olmalarını, hiç bir matematiksel nense yoktur. ${ }^{4}$

Bunlar ayrı ayrı meselelerdir ve Jordan Howard Sobel gibi argümanın son dönem eleştirmenleri tarafindan bir arada sunulmuştur: Logic and Theism: Arguments for and against Beliefs in God. Cambridge: Cambridge University Press, 2004), ss.181-9, 198-9; Graham Oppy, Philosophical Perspectives on Infinity (Cambridge: Cambridge University Press, 2006), ss.291-3.

Bkz. Mark Balaguer, Platonism and Anti-Platonism in Mathematics (New York: Oxford University Press, 1998), part II; a. mlf., "A theory of Mathematical Correctness and Mathematical Truth," Pacific Philosophical Quarterly 82 (2001), ss.87-114; Stanford Encyclopedia of Philosophy, s.v. "Platonism in Metaphysics," by Mark Balaguer (Summer 2004), ed. Edward N. Zalta, http://plato.stanford.edu/archives/sum2004/entries/platonism/; Stephen Yablo, "A Paradox of Existence," Empty Names, Fiction, and the Puzzles of Non-Existence, ed. Anthony Everett and Thomas Hofweber (Stanford: Center for Study of Language and Information, 2000) içinde, ss.275312; a. mlf., "Go Figure: A Path through Fictionalism," Figurative Language, ed. Peter A. French 
Bir kişi, tutarlı bir şekilde kabul edebilir ki bilfiil sonsuz, postulat olarak sunulan söylem evreni içerisinde verimli ve insicamlı bir kavram olsa da gerçek dünyaya aktarılamaz, zira bu sezgiye aykırı (counter-intuitive) saçmalıklar içerecektir.

4. öncüle destek sağlamanın en iyi yolu, bilfiil bir sonsuzun gerçek dünyada müşahhas örneğinin olması durumunda ortaya çıkacak çeşitli saçmalıkları gösteren düşünce-deneyleri yapmaktır. Bu tür düşünce deneylerini tertip etmede hassaten yaratıcı ve etkili olan José Benardete, bunu iyi ifade etmektedir: "Soyut olarak bakılınca, bu büyüklüklerin hiç birinde mantıksal çelişki bulunmaz; fakat somut olarak, suratımızın tam ortasına çarpacak korkunç saçmalıklarıyla yüzleşmek zorundayız.",

Sadece bir örneğe bakalım: David Hilbert'in meşhur buluşu "Hilbert'in Oteli." Isınma tur için önce sonlu sayıda odası olan bir otel hayal edelim. Bunun yanı sıra, odaların hepsinin tutulmuş olduğunu farzedelim. Yeni bir misafir gelip bir oda isteyince, mal sahibi "Kusura bakmayın, bütün odalar dolu" diye özür diler ve hikaye orada biter. Fakat şimdi gelin sonsuz sayıda odas1 olan bir otel hayal edelim ve bir kere daha bütün odaların tutulmuş olduğunu farzedelim. Bu sonsuz otelin tümünde bir tek boş oda bile yoktur. Şimdi diyelim ki oda isteyen yeni bir misafir çıkıp geliyor. "Tabii, elbette!" diyor mal sahibi ve hemen 1 numaralı odadaki kişiyi 2 numaralı odaya, 2 numaralı odadaki kişiyi 3 numaralı odaya, 3 numaralı odadaki kişiyi 4 numaralı odaya kaydırıyor ve bu şekilde sonsuza kadar devam ediyor. Bu oda değişikliklerinin sonucu olarak, 1 numaralı oda boşalıyor ve yeni misafir minnettar bir şekilde odasını tutuyor. Fakat hatırlayınız, o varmadan önce bütün odalar tutulmuştu! Eşit derecede garip olarak, şu anda otelde öncekinden daha fazla sayıda kişi bulunmuyor: sayı, sadece sonsuz. Fakat nasıl olur bu? Mal sahibi daha şimdi yeni misafirin ismini kayıtlara ekledi ve ona anahtarlarını verdi-nasıl olur da otelde öncekinden daha fazla kişi olmaz?

and Howard K. Wettstein, Midwest Studies in Philosophy 25 (Oxford: Blackwell, 2001) içinde, ss.72-102; Charles S. Chihara, Constructibility and Mathematical Existence (Oxford: Clarendon Press, 1990); a.mlf., A Structural Account of Mathematics (Oxford: Clarendon Press, 2004).

$5 \quad$ José A. Benardete, Infinity: An Essay in Metaphysics (Oxford: Clarendon Press, 1964), s.238. Özellikle onun tırtıklı/çentikli sürekliliğin paradoksları (paradoxes of the serrated continuum) diye adlandırdı̆̆ şeye bkz. (ss.236-237).

6 Hilbert'in Hoteli hikayesi, George Gamow, One, Two, Three, Infinity (London: Macmillan, 1946), s.17'de anlatılmaktadır. 
Ama durum daha da tuhaf hale geliyor. Zira farzedelim ki sonsuz sayıda yeni misafirler geliyor ve oda istiyorlar. "Elbette, elbette!" diyor mal sahibi ve 1 numaralı odadaki kişiyi 2 numaralı odaya, 2 numaralı odadaki kişiyi 4 numaralı odaya, 3 numaralı odadaki kişiyi 6 numaralı odaya kaydırıyor ve bu şekilde sonsuza kadar devam ediyor; ve daima her bir önceki misafiri, kendi numarasının iki katı numaralı odaya koyuyor. İki ile çarpılan her hangi bir sayı daima bir çift sayıya denk olduğu için, bütün misafirler çift-sayılı odalara konuluyorlar. Netice olarak, bütün tek-sayılı odalar boşalıyor ve sonsuz sayıda yeni misafirler kolayca yerleştiriliyorlar. Öyle olsa da, onlar gelmeden önce bütün odalar tutulmuştu! Ve yine tuhaf bir şekilde sonsuz sayıda yeni misafirin otelde oda tutmalarından sonra oteldeki misafirlerin sayıs1, öncekiyle aynıdır, sanki eski misafirlerin sayısı kadar yeni misafir varmış gibi. Aslında mal sahibi, bu işlemi sonsuz sayıda çok kere tekrar edebilir ve hala otelde asla öncekinden fazla olan bir tek kişi bile olmaz.

Fakat Hilbert'in oteli, bu Alman matematikçinin gösterdiğinden bile daha tuhaftır. Zira farzedelim ki misafirlerden bazıları otelden ayrılmaya başl1yor. Diyelim ki 1 numaralı odadaki misafir ayrılıyor. Şu anda otelde daha az sayıda insan yok mudur? Transfinite (sonlu ötesi) aritmetiğe göre hayır! Farzedelim ki 1, 3, 5, ... numaralı odalardaki misafirler ayrıldılar. Bu durumda, sonsuz sayıda insan otelden ayrılmıştır, fakat oteldeki insan sayısı daha az değildir. Aslında biz her iki misafirden birinin otelden ayrılmasını sağlayabiliriz ve bu işlemi sonsuz kere tekrarlayabiliriz; ve hala otelde asla daha az sayıda insan olmaz. Şimdi diyelim ki mal sahibi yarısı boş bir otel istemiyor (bu iş açısından kötü gözükür). Önemli değil! Çift-sayılı odalarda kalan misafirleri, kendi oda numaralarının yarı değerindeki sayıya sahip odalara kaydırarak, mal sahibi yarı-boş olan otelini tamamen dolu olan bir otele dönüştürür.

Kişi, bu türlü manevralarla mal sahibi sürekli olarak bu tuhaf oteli tamamen dolu tutabilir diye düşünebilir, ama yanılır. Zira diyelim ki 4, 5, 6, .. numaralı odalardaki misafirler otelden ayrildılar. Otel tek bir hareketle tamamen boşaltılabilir, misafir kayıtları üç isme indirilebilir ve sonsuz olan sonluluğa çevrilebilir. Ama şurası hala doğrudur ki bu defa 1, 3, 5 ... numaralı odalardaki misafirlerin ayrıldıkları zamanki kadar çok sayıda misafir ayrılmıştır! Böyle bir otelin gerçekte var olabileceğine kimse inanabilir mi? 
Hilbert'in Oteli saçmadır. Fakat eğer bilfiil bir sonsuz metafiziksel açıdan mümkün olsayd1, o zaman böyle bir otel metafizik olarak mümkün olurdu. Buradan çıkan şudur ki bilfiil bir sonsuzun gerçek varlığı metafizik olarak mümkün değildir.

Argümanın eleştirmeni bu noktada ne söyleyebilir? Onun, Graham Oppy'nin ifadesiyle, kendisinin abese irca (saçmalı̆ga indirgeme $=$ reductio ad absurdum) argümanının sonucunu benimseyerek aklen argümanın savunucusunun üstesinden gelmeye çalışmaktan başka seçeneği yoktur: Hilbert'in Oteli yine de mümkündür. ${ }^{7}$ Aklen üstün gelme stratejisinin bariz mahzuru, bunun, insan benimseme cüretine sahip olduğu sürece, ne kadar saçma olursa olsun, her hangi bir sonucu meşrulaştırmak için kullanılabilir olmasıdır. İstediğimiz şey, böylesi bir otelin gerçekten mümkün olduğunu düşünmek için bir sebeptir. Burada Oppy'nin şundan başka diyecek bir şeyi yoktur: "şayet ... fiziksel sonsuzluklar varsa, bu saçma olduğu iddia edilen durumlar, tam da kişinin beklemesi gereken şeylerdir." ${ }^{8} \mathrm{Bu}$ cevap, aslında sadece, eğer bilfiil bir sonsuz var olsaydı, o zaman tartışmalı olmayan ilgili keyfiyetlerin ortaya çıkacağını tekrar etmektedir. Eğer iddia edilen sonuçlar müteakiben ortaya çıkmasaydı, problem durumlar da problemli olmazdı! Soru, daha ziyade, bu sonuçların gerçekten saçma olup olmadıklarıdır.

Bütün taraflar ittifak ettiler ki eğer bilfiil sonsuz sayıda şeyler var olsayd1, o zaman kendimizi Hilbert'in Oteli gibi garipliklerle dolu bir Alice Harikalar Diyarında dünyasına inmiş bulmalıyız. Basitçe "Eğer fiziksel sonsuzluklar olsayd1, bu durumlar tam da bizim beklememiz gereken şeyler" olduğunu tekrar etmek, insanın, bu tür bir dünya metafizik açıdan saçmadır şeklindeki kuşkusunu teskin etmeye yardım etmez. Ayrıca, Oppy'nin, tıpkı sonsuz sayıda misafirlerin otelden ayrıldığında olduğu üzere, sonsuz niceliklerden eksiltme yapmak gibi ters işlemler (inverse operation) olduğunda nelerin olacağ 1 hakkında söyleyecek hiç bir şeyi yoktur. Transfinite (sonlu-ötesi) aritmetikte, ters çıkarma ve bölme işlemleri yasaktır, çünkü bunlar çelişkilere götürmektedir; fakat realitede, istedikleri takdirde insanların otelden ayrilmalarına kimse engel olamaz.

Oppy, Philosophical Perspectives on Infinity, s.48; krş. John L. Mackie, The Miracle of Theism (Oxford: Clarendon Press, 1982), s.93; Sobel, Logic and Theism, ss.186-7.

Oppy, Philosophical Perspectives on Infinity, s.48. 
Zaman içinde başlangıçsız olaylar dizisi, bilfiil sonsuz sayıda şeyleri gerektirmektedir. $\mathrm{Bu}$ öncül hayli açıktır. Eğer alemin hiçbir zaman başlangıcı yok idiyse, o zaman mevcut olayın öncesinde bilfiil sonsuz sayıda sabık olaylar var olmuştur. Böylece, zamanda başlangıçsız olaylar dizisi, bilfiil sonsuz sayıda eşyayı yani olayları gerektirmektedir.

Şu halde, zamanda başlangıçsız olaylar dizisi var olamaz. Eğer yukarıdaki iki öncül doğruysa, o zaman mantıkan bu sonuç çıkar. Geçmiş olaylar dizisi, sonlu olmak ve bir başlangıca sahip olmak zorundadır. Alem, bu olaylar dizisinden ayrı olmadığına göre, dolayısıyla alemin bir başlangıcı vardır.

\section{Bilimsel Kanıt:}

\section{Evrenin Genişlemesi}

Şimdi, halihazırda yalnızca felsefi argümanın ulaştığı sonucun bilim tarafından çarpıcı bir şekilde teyidini incelemeye geçiyorum. Alemin başlang1cına dair fiziksel kanıt, günümüzde bilimin hiç kuşkusuz en heyecan verici ve en hızlı gelişen alanlarından birinden çıkmaktadır: astronomi ve astrofizik. 1920'lerden önce bilim adamları hep alemin durağan ve ezeli olduğunu varsaymışlardı. Bu geleneksel kozmolojiyi yıkacak yaklaşan depremin sarsıntıları, önce 1917'de, Albert Einstein yeni keşfettiği yerçekimsel teorinin, yani Genel İzafiyet Teorisi'nin kozmolojik uygulamasını yaptığı zaman hissedildi. Einstein, kendisine hayal kırıklığ 1 yaşatacak şekilde, maddenin çekimsel etkisini dengelemek amaciyla denklemleri tahrif etmediği takdirde, teorisinin ezeli, statik evren modeline izin vermediğini gördü. Sonuç olarak Einstein'in evreni müşkil bir durumda dengeye oturtuldu ve en ufak bir sarsılma - ve hatta maddenin evrenin bir kısmından başka bir kısmına taşınmas1 bile- evrenin ya patlamasına veyahut genişlemesine yol açacaktı. Einstein'in modelinin bu özelliğini ciddiye alarak Rus matematikçi Alexander Friedman ve Belçikalı astronom Georges Lemaitre, 1920'lerde birbirlerinden bağımsız olarak onun genişleyen bir evren öngören denklemlerine çözümler geliştirebildiler.

1929'da Amerikalı astronom Edwin Hubble, uzak galaksilerden gelen 1şığın sistematik bir şekilde spektrumun kırmızı sınırına kaydığını ortaya koydu. Bu kırmızıya kayma olayı, 1şık kaynağının görüş hattında uzaklaştığını (geriye çekildiğini) gösteren bir Doppler etkisi olarak kabul edildi. İna- 
nılmaz bir şekilde, Hubble'ın keşfettiği şey, Einstein'in Genel İzafiyet Teorisine dayalı olarak Friedman ve Lemaitre tarafından öngörülen evrenin genişlemesiydi. Bu, bilim tarihinde hakiki bir dönüm noktasıydı. "Bilimin yüzyıllardır yaptığı bütün büyük öngörüler arasında," hayretini ifade ediyor John Wheeler, "öngören ve doğru bir şekilde öngören ve evrenin genişlemesi kadar fevkalade bir fenomeni bütün beklentilere karşın öngören bundan daha büyük bir öngörü var mıydı?" 9

Friedman-Lemaitre modeline göre, zaman ilerledikçe galaksileri ayıran mesafeler büyümektedir. Şunu takdir etmek önemlidir ki Genel İzafiyet Teorisine dayalı bir model olarak, bu model evrenin maddi muhtevasının daha önce var olan boş uzay içindeki genişlemesini değil, fakat daha ziyade bizzat uzayın genişlemesini tasvir etmektedir. Galaksiler, uzaya nisbetle sükun halinde, fakat uzayın kendisi genişledikçe veya yayıldıkça birbirinden kademeli olarak uzaklaşan bir şekilde tasavvur edilmektedir, tıpkı bir balonun yüzeyine yapıştırılmış düğmelerin, balon şişirildikçe birbirinden uzaklaşması gibi. Bu durum, şu hayret verici imaya sahiptir: bir kişi genişlemeyi geri döndürüp zaman içerisinde geriye yönelik çıkarsamalar yaptıkça, sonlu geçmişte bir noktada sonsuz bir yoğunluk haline ulaşıncaya kadar, evren kademeli olarak daha yoğun hale gelir. Bu hal, 1s1, basınç ve yoğunluğun yanı sıra uzay-zaman eğrisinin sonsuz hale geldiği bir 'singülarite'yi (tekillik) temsil etmektedir. Bu sebeple o, uzay-zamanın bizzat kendisi için bir kenar veya hudut oluşturmaktadır. Aslında Friedman-Lemaitre modelinin öngördüğü evrenin başlangıcını nitelemek için Fred Hoyle tarafindan alaycı bir ifadeyle icat edilen "Big Bang" (Büyük Patlama) terimi, dolayısıyla potansiyel olarak yanıltıcıdır, zira genişleme dışarıdan görsel hale getirilemez ([çünkü] “dışarı" yoktur, tıpkı Big Bang'le ilgili olarak "önce”nin olmadığg gibi).

Friedman-Lemaitre modeline verilen isim olarak, standard Big Bang modeli, böylece geçmişte ezeli olmayan fakat sonlu bir zaman önce varlığa çıkan bir evren tasvir etmektedir. Ayrıca, —ve bu, altı çizilmeyi hak ediyor- onun öne sürdüğü orijin/başlangıç/menşe, yoktan çıkan mutlak bir başlangıçtır. Zira sadece bütün madde ve enerji değil, aynı zamanda bizzat uzay ve zaman da ilk kozmolojik singülaritede varlığa çıkmaktadırlar. Fizik-

John A. Wheeler, "Beyond the Hole," Some Strangeness in the Proportion, ed. Harry Woolf (Reading, Mass.: Addison-Wesley, 1980) içinde, s.354. 
çiler John Barrow ve Frank Tipler'in vurguladıkları gibi, "Bu singülaritede, uzay ve zaman varlığa çıktılar; bu singülariteden önce, literal olarak hiçbir şey var değildi; dolayısıyla, eğer evren böyle bir singülaritede ortaya çıktıysa, [o zaman] hakikaten bir yoktan yaratmaya sahip oluruz." ${ }^{10}$ Böyle bir model göre, evren yoktan neşet etmiştir, şu anlamda ki ilk singülaritede "Daha önce uzay-zaman noktasl yoktur" [ifadesi] doğrudur veya "Singülariteden önce bir şey vardl" [ifadesi] yanlıştır.

İmdi, böyle bir sonuç, onun hakkında kafa yoran birisi için muazzam derecede rahatsız edicidir. Zira [şu] soru örtbas edilemez: Evren niçin varlı$\breve{g} a$ çıktı? Evrenin başlangıcını tefekkür eden Sir Arthur Eddington, nihayetinde şu sonuca varmaya mecbur kaldığını hissetti: "Başlangıç, üstesinden gelinemez zorluklar sunuyor gözükmektedir, eğer ona dürüst bir şekilde tabiatüstü olarak görmezsek." "Dolayısıyla, astrofizikçi bir ekibin ifadesiyle, evrenin başlangıcı problemi, "çekici veyahut tiksindirici olabilecek belli bir metafiziksel veche içermektedir."12

Evrenin mutlak bir başlangıcı düşüncesi tarafından sunulan katı metafiziksel alternatiflerden ürperen bazı teorisyenler, anlaşılır bir şekilde, standard modeli yıkmaya ve ezeli bir evreni restore etmeye heveslidirler. Günümüze kadar böylesi hiçbir teşebbüs başarılı olmamıştır. Sürekli yaratma modelleri, klasik salınan evrenler modelleri ve boşluk dalgalanması modelleri, geldiler ve gittiler. Bugün şayet standard modelin evrenin mutlak bir başlangıcına dair öngörüsü def edilecekse, kurtuluş, kozmogoni yani ezeli şişme/şişkinlik veya kuantum çekimi konularındaki halihazırda devam eden araştırma programlarından biri vasıtasıyla gelecektir.

Ancak, 1994'de Arvind Borde ve Alexander Vilenkin gösterdiler ki geleceğe doğru ezeli olarak şişen her hangi bir uzay-zaman, geçmişte "jeodezik olarak tamamlanmış" olamaz; bu demektir ki belirsiz geçmişte bir noktada bir ilk singülarite var olmuş olmalıdır. Bu sebeple, şişme senaryosu ezeli olamaz. 2003'te Borde ve Vilenkin, Alan Guth ile işbirliği içerisinde, ezeli şişme taraftarlarının kendi teorilerini kurtarmak için inkar etmiş olabilecekleri "zayıf enerji hali" (weak energy condition) diye isimlendirilen teorinin varsayımından bağımsız yeni bir teorem icat ederek ulaştıkları sonucu des-

\footnotetext{
10 John Barrow and Frank Tipler, The Anthropic Cosmological Principle (Oxford: Clarendon Press, 1986), s.442.

A.g.e., s.178

12 Hubert Reeves, Jean Audouze, William A. Fowler, and David N. Schramm, "On the Origin of Light Elements," Astrophysical Journal 179 (1973), s.912.
} 
tekleme imkanı buldular. ${ }^{13}$ Yeni teoremleri, Vilenkin'in ifadesiyle, "o kapıyı tamamen kapatacak gözükmektedir." " Onların bu yeni teorisi tek bir varsayıma sahiptir: evren, ortalama olarak, tarih boyunca kozmik genişleme hali içerisindedir. Bu şartı karşılayan her hangi bir evren hakkında, mevcut durumdan yola çıkılarak sonsuz geçmişi kapsayacak şekilde çıkarsama yapılamaz.

Daha güçlü teoremlerinin formülasyonuyla Borde, Guth ve Vilenkin, şişmeci modellere dair daha önceki sonuçlarını, ulaştıkları neticeyi diğer modellere şamil kılacak şekilde genelleme imkanına kavuştular. Aslında, bu yeni teorem, müspet bir oranda küresel olarak genişlemekte olan her hangi bir evrenin geçmişte jeodezik olarak tamamlanmamış olduğunu ve bu sebeple geçmişte bir sınırı olduğunu ima etmektedir. Onlar hassaten, "Bizim argümanımız, doğrudan, daha yüksek boyutlarda kozmolojiyi kapsayacak şekilde genişletilebilir," özellikle de "brane-kozmoloji."15 Vilenkin'e göre, "Bizim teoremden, dairesel evrenin geçmiş açısından tamamlanmadığı çıkmaktadır," ğildir.

Önceleri, evrenin mutlak başlangıcından kaçınmaya odaklanmış teorisyenler, daima Planck Zamanı'ndan önceki dilime sığınabilirlerdi, ki [Planck Zamanı], o kadar yetersiz anlaşılmıştır ki bir yorumcu onu kadim haritacıların haritalarında "Burada ejderhalar bulunur" diye işaretlenen bölgelerle mukayese etmiştir-yani her türlü hayali yaratıklarla doldurulabilecek bir yerle. Fakat Borde-Guth-Vilenkin teoremi, Planck Zamanından önceki evrenin belli bir fiziksel tasvirine dayanmamakta, bunun yerine bizim o çağla ilgili kesinsizliğimize bakılmaksızın geçerli olacak yanıltıcı derecede basit fiziksel muhakemeye dayanmaktadır. Vilenkin, söyleyeceklerinden geri durmuyor: "Denir ki bir argüman makul bir insanı ikna eden şey, bir delil/kanıt ise makul olmayan birini bile ikna etmek için gereken şeydir. Ortaya konan kanıtla, kozmolojistler artık ezeli bir evrenin imkanının ardına sakla-

\footnotetext{
13 Arvind Borde, Alan Guth, and Alexander Vilenkin, "Inflation Is Not Past-Eternal," http://arXiv:grqc/0110012v1 (1 Oct 2001): 4. Makale, Ocak 2003'te güncellendi.

14 Alexander Vilenkin, "Quantum Cosmology and Eternal Inflation," http://arXiv:gr-qc/0204061v1 (18 Nisan 2002), s.10.

15 Borde, Guth, and Vilenkin, "Inflation Is Not Past-Eternal," s.4. Ayrica bkz. Alexander Vilenkin, "Quantum cosmology and eternal inflation," The Future of Theoretical Physics and Cosmology, Proceedings of the conference in honor of Stephen Hawking's 60th birthday (2002) içinde, bask1öncesi: http://arxiv.org/abs/gr-qc/0204061, s.11. 
namazlar. Kaçış yok, onlar bir kozmik başlangıç problemiyle yüzleşmek zorundadırlar." 17

Borde-Guth-Vilenkin teoremi şimdi kozmolojistler tarafından yaygın olarak kullanılmaktadır. Sonuç olarak, evrenin başlangıcını bertaraf eden teorisyenler o teoremin tek varsayımını inkar etmeye mecburdurlar: evrenin tarihi, kozmik genişleme tarihidir. $\mathrm{Bu}$ ise şu zanları içeren spekülatif evren modellerine yol açmıştır: Big Bang öncesinde ezeli geçmişten beri sonsuz daralma, veya sonsuz geçmişte var olan ve kendisinden evrenin ortaya çıtığ1 statik bir hal, veya gözlemlenen genişleme öncesindeki sonsuz salınımlar dizisi, veya hatta bizzat zamanın yapıçözümü (dekonstrüksiyonu). Bütün bu zanlar/yorumlar hem gözlemsel olarak hem de teorik olarak görünürde aş1lmaz zorluklarla karşılaşmaktadır. ${ }^{18} \mathrm{Bu}$ sebeple, şu ana kadar hiçbir makul teori, standard modelce öngörülen başlangıcı bertaraf etmeyi başaramamıştır.

Elbette, evrenin bir başlangıcı olduğu ihtimaliyle gündeme gelen metafiziksel meseleleri hesaba katınca, standard modelin öngördüğü mutlak başlangıcı savuşturma arayışının zayıflamadan devam edeceğinden emin olabiliriz. $\mathrm{Bu}$ tür çabalar, teşvik edilmelidir; ve Standard modelin öngörüsünün yanlışlanmasına yönelik böylesi teşebbüslerin, o modelin başlangıç öngörüsünün teyidinden başka bir şeyle sonuçlanacağını düşünmek için hiçbir sebebimiz yoktur. Bilimsel kanıt her zaman muvakkat olsa da kanıtın işaret ettiği bu hususta çok az kuşku olabilir.

\section{EVRENIN NEDENI}

Geçmişin sonlu oluşuna dair argümanımıza dayalı olarak, baştaki argümanımızın ikinci öncülünü - alemin başlangıcı vardır - onaylamak için iyi bir temele sahibiz. İlk öncülden -yani, başlangıcı olan her şeyin bir sebebi vardır - ve ikinci öncülden, mantıkan evrenin bir sebebi vardır sonucu çıkmaktadır. Bu sonuç afallatıcıdır, zira bu, alemin, kendisinden daha büyük ve kendisinin ötesinde olan bir şey tarafindan varlığa çıkarıldığı anlamına gelmektedir.

Kavramsal analiz, bizim böylesine evren-ötesi bir varlığın sahip olması gereken bir takım çarpıcı vasıfları ortaya çıkarmamıza imkan vermektedir. Zira mekan ve zamanın nedeni olarak bu entite, mekan ve zamandan aşkın

Vilenkin, Many Worlds in One, s.176.

Tartışma için bkz. William Lane Craig and James Sinclair, "The Kalam Cosmological Argument," Blackwell Companion to Natural Theology, ed. Wm. L. Craig and J. P. Moreland (Oxford: Blackwell, 2009) içinde. 
olmalıdır ve bu sebeple zamansız ve mekansız (en azından evren olmaksızın) var olmalıdır. ${ }^{19} \mathrm{Bu}$ aşkın neden, dolayısıyla değişmez ve gayr-i maddi olmalıdır, çünkü zamansızlık değişmezliği gerektirir; ve değişmezlik ise gayr-i maddiliği ima eder. Böyle bir neden, başlangıçsız ve nedensiz olmalıdır, en azından daha önce gelen nedensel şartlardan yoksunluk anlamında, zira geriye doğru sonsuz bir nedenler teselsülü olamaz. Ockham'ın Usturası (yani, 'nedenleri gerektiğinden fazla çoğaltmamalıyız' şeklindeki prensip), fazladan nedenleri traşlayacaktır. Bu entite, hayal edilemez şekilde kudretli olmalıdır, zira o, alemi her hangi bir maddi illet olmaksızın yaratmıştır.

Son olarak ve en dikkate değer olarak, böyle bir aşkın nedenin makul bir şekilde kişi/kişisel olduğu kabul edilmelidir. Alemin nedeninin şahıs oluşu, onun zamansızlığ ve gayr-i maddiliği tarafından ima edilmektedir. Bizim bu türe niteliklere sahip olduğunu bildiğimiz entiteler, diğer zihinler veya sayılar gibi soyut nesnelerdir. Fakat soyut nesneler, nedensel ilişkiler içinde yer almazlar. Aslında onların nedenleyici olmayan tabiatı, soyut nesneler için belirleyicidir; bu sebeple onlara soyut diyoruz. ${ }^{20}$ Örneğin sayılar hiçbir şeyi nedenleyemezler. Dolayısıyla, evrenin doğuşunun aşkın nedeni, cisimden ari kişisel bir zihin olmalıdır. Ve bu, Thomas Aquinas'ın söylemeyi adet edindiği gibi, herkesin "Tanrı" derken kastettiği şeydir.

İmdi, bazı düşünürler, zamansız, kişisel bir ilaha dair çizdiğim bu resme itiraz ettiler, zira böyle bir varlık kişiler-arası ilişkilerden yoksundur ve böylesi ilişkiler onlara göre şahıslık için elzemdir. Eğer Tanrı kişisel olacaksa, O diğer kişilerle ilişkiye girmek zorundadır. Fakat kişisel ilişkilerin alış-verişi zamansallığ gerektirir.

$\mathrm{Bu}$ itirazın temelinde yer alan varsayım, Tanrı'yla ilişkilendirilen kişilerin insan kişiler olması gerektiğidir. Fakat en azından Hıristiyan Tanrı anlayışına göre, bu varsayım yanlıştır. Bizatihi ilahi varlığın tamlığı içerisinde, Baba, Oğul, Kutsal Ruh şahısları, Tanrı demek olan Üçlü-Birlik'in (Teslis) sunduğu şahıslar-arası ilişkileri yaşamaktadırlar. Bir Üçlü-Birlik olarak Tanrı, sonlu kişilerin refakatine ihtiyacı olmaksızın ezeli olarak kamildir. Tanrı'nın özgürce sonlu kişiler yaratması ve onları Tanrı'nın içsel Üçlü-Birlik hayatının sevgisine ve hazzına katılmaya davet etmesi, O'nun lütfunun ve sevgisinin bir mucizesidir.

\footnotetext{
19 Veyahut diğer bir seçenek olarak, neden, içerisinde zamansal aralıkların temyiz edilemediği farkl1laşmamış bir zaman içerisinde değişmez olarak vardır. Bu görüşe göre Tanrı, literal olarak, yaratılıştan önce vardı, fakat, örneğin yaratılıştan bir saat veya bir milyon yıl önce hiçbir an yoktu. 
Fakat bu Üçlü-Birlik’teki karşılıkl1-ilişkilerin (inter-relations) varlığı, Tanrı'nın zamansal olmasını zorunlu kılar mı? Üçlü-Birlik'i oluşturan şahısların, değişmez ve dolayısıyla zamansız bir şekilde etkilenmiş, harekete geçirilmiş veya birbirlerine duyarlı olamaması için hiçbir sebep görmüyorum. Dünyevi bir örnek kullanırsak, bir mıknatısa yapışan demir talaşları düşünün. Talaşların, mıknatısın onları etkilemesinden ve onların da mıknatısın gücüne karşıl1k vermelerinden ötürü mıknatısa yapışık olmaları durumunun meydana gelmesi için mıknatıs ve talaşların hiç bir şekilde konumlarını değiştirmeleri gerekmez. Bu örnek, makro düzlemde eylem ve karş1lığın nasıl eş-zamanlı olabileceğini ve dolayısıyla ne değişim ne de zamansal ayrılık gerektirmediğini betimlemektedir. Teslisin kişileri arasındaki ilişkileri düşündüğümüzde, bu ne kadar fazlasıyla böyledir! Teslis-içi ilişkiler fiziksel etkilere dayalı olmadığı veya herhangi bir maddi mahalde değil fakat tamamen zihinsel bir temelde/mahalde yerleşik olduğu için, Oğul'un Baba'nın sevgisine karşılık vermesi, ne değişim ne de zamansal ayrılık içerir. Nasıl ki bir kelime bile etmeden oturmuş birbirlerinin gözlerine bakan iki sevgiliden mecazen "o zamansız anda kaybolmuşlar" diye bahsedebiliyorsak, aynı şekilde Baba, Oğul ve Ruh'un birbirleri için karşılıklı zamansız sevgilerinden de literal olarak bahsedebiliriz.

Kapadokya Kilise Babası Nenizili Gregorius'un savunuculuğunu yaptığ 1 kadim perichoreisis öğretisi, uluhiyetin kişileri arasındaki zamansız etkileşimi aydınlatmaktadır. Bu öğretiye göre, Üçlü-Birlik'in şahısları arasında tam bir iç içe geçme vardır, öyle ki her biri diğerinin faaliyetleriyle bir bütün oluşturacak şekilde sımsıkı bağlıdır. Böylece Baba'nın irade ettiği şeyi, Oğul ve Ruh da irade eder; Oğul'un sevdiğini, Baba ve Ruh da sever, vs. Her bir şahıs, diğerlerine tamamen şeffaftır. Örneğin Oğul'un Ruh'a iletebileceği yeni hiçbir şey yoktur, çünkü o zaten iletilmiştir. İlahi sevgi ve bilginin tam ve mükemmel bir teatisi vardır, öyle ki tamamlanması gereken hiçbir şey yapılmamış bırakılmaz. İlahi sevgi ve hayatın bu mükemmel iç içe geçmişliğinde hiçbir değişmenin vuku bulması gerekmez, öyle ki Kendi varlığının kendine yeterliliği tek başına var olan Tanrı, ilişkisel bir zaman görüşüne göre, zamansız olur. Dolayısıyla, Tanrı'nın kişiler-arası ilişkileri yaşayabileceği ve yine de zamansız olabileceğinin açık olduğunu düşünüyorum.

Argümanımızın ima ettiği sonucun kavramsal bir analizine dayanarak alemin, nedensiz, başlangıçsız, değişmez, gayr-i maddi, zamansız, mekansız ve hayal edilemez derecede kudretli olan kişisel bir Yaratıcısının var olduğunu çıkarsayabiliriz. 